\title{
Assessing Bioenergy Harvest Risks: Geospatially Explicit Tools for Maintaining Soil Productivity in Western US Forests
}

\author{
Mark Kimsey, Jr. ${ }^{1, *}$, Deborah Page-Dumroese ${ }^{2}$ and Mark Coleman ${ }^{1}$ \\ 1 Intermountain Forest Tree Nutrition Cooperative, Department of Forest Ecology and \\ Biogeosciences, University of Idaho, P.O. Box 441133, Moscow, ID 83844-1133, USA; \\ E-Mail: mcoleman@uidaho.edu \\ 2 US Forest Service, Rocky Mountain Research Station, 1221 South Main Street, Moscow, ID 83843, \\ USA; E-Mail: ddumroese@fs.fed.us \\ * Author to whom correspondence should be addressed; E-Mail: mkimsey@uidaho.edu; \\ Tel.: +1-208-885-7520; Fax: +1-208-885-7442.
}

Received: 21 July 2011; in revised form: 9 September 2011 / Accepted: 14 September 2011 / Published: 20 September 2011

\begin{abstract}
Biomass harvesting for energy production and forest health can impact the soil resource by altering inherent chemical, physical and biological properties. These impacts raise concern about damaging sensitive forest soils, even with the prospect of maintaining vigorous forest growth through biomass harvesting operations. Current forest biomass harvesting research concurs that harvest impacts to the soil resource are region- and site-specific, although generalized knowledge from decades of research can be incorporated into management activities. Based upon the most current forest harvesting research, we compiled information on harvest activities that decrease, maintain or increase soil-site productivity. We then developed a soil chemical and physical property risk assessment within a geographic information system for a timber producing region within the Northern Rocky Mountain ecoregion. Digital soil and geology databases were used to construct geospatially explicit best management practices to maintain or enhance soil-site productivity. The proposed risk assessments could aid in identifying resilient soils for forest land managers considering biomass operations, policy makers contemplating expansion of biomass harvesting and investors deliberating where to locate bioenergy conversion facilities.
\end{abstract}


Keywords: forest soil productivity; soil disturbance; GIS; best management practices

\section{Introduction}

The demand for forest products is projected to increase with global population growth over the next century, while actively managed forest land is projected to significantly decrease [1]. The search for carbon neutral alternative energy sources, including forest bioenergy, further increases pressure on the productive capacity of the forest land base. These increasing demands on forest production capacity raise concerns over the capability of forest lands to meet society's demand for forest products. Can forest soils in the western US support more intensive timber harvesting for both traditional and emerging bioenergy markets? Is it reasonable to assume that biomass harvesting and sustainable soil productivity are compatible? Both private and public forest land holders seek answers to these questions for both economic and environmental reasons.

Private sector forestry in the western US is under intense domestic and global competition in the wood products market $[2,3]$. To meet changes in global market competition, private forest land holders are shifting rapidly from extensive forestry to intensive forestry [1,4,5]. Concomitantly, what was traditionally left as biomass residue following either pre-commercial and commercial thinnings or regeneration harvests, are now under consideration as further streams of revenue and bioenergy from the burgeoning "green economy" [6]. The primary question for private forest land holders then becomes, how does intensive forestry, and perhaps utilization of harvest "waste" for bioenergy, affect long-term soil-site productivity and thus long-term net revenue?

For public sector forest management the issue is not whether to be globally competitive in the forest products market, but how to maintain forest health and site productivity [7]. Decades of fire suppression and changing climatic patterns have left many western forests overstocked and prone to insect and disease attack and catastrophic wildfire events [8,9]. Further exacerbating forest health problems, is the fact that public land management agency budgets are shrinking, decreasing their capacity to improve forest conditions. Thus, the question for public land managers is twofold: (1) can emerging biofuel markets offset the cost of forest improvement treatments; and (2) how does removal of biomass affect soil-site properties and thus future productivity?

In this paper, we synthesize the numerous articles on forest biomass harvesting [10-16] and harvesting effects on soil-site productivity [5,7,17-23] to focus on how this information can be used by natural resource managers and/or policy makers. Our intention is to demonstrate how these findings can be used in an applied setting.

Generally, all forest soil productivity research to date supports the following statement: forest harvest treatments will alter soil physical, chemical, and biological properties [5]. The degree and extent of this disturbance is usually site specific [16]. Soil disturbance is primarily attributed to soil compaction and displacement of organic matter rich duff and mineral soil by either tracked or rubber-tired ground-based harvest systems [24,25]. Reeves et al. [26] estimated that ground-based harvest equipment can disturb up to 15 percent of a unit depending on season and landform. In a summary of disturbance effects on subsequent forest productivity, Grigal [5] loosely estimates that 
approximately 10 percent of forest productivity is lost following a typical harvest treatment in Douglas-fir and ponderosa pine forests of the western US. However, other research, including that of Grigal [5], have shown that forest productivity loss following harvesting activities is not uniformly observed. Soil disturbance impacts on second rotation vegetation growth has shown positive, negative or no effect, depending on site-specific attributes [16].

Widely divergent responses to similar harvest treatments can be generally summed as a function of forest floor depth (all organic horizons), soil organic matter content, soil texture, quantity of coarse fragments, soil depth and mineralogy [16,27]. Deeper, fine-textured soils typically display decreases in forest productivity following compaction and displacement, but are less likely than coarse-textured soils to have productivity reductions due to nutrient removal (biomass harvesting). In contrast, shallower, coarse-textured soils are more likely to manifest an increase in productivity following some level of compaction; but are more susceptible to productivity declines following biomass removal or litter/topsoil displacement $[16,28]$. Pore size redistribution and shifts in soil mineralization rates are responsible for these observed patterns [13]. Compaction of fine-textured soil causes suboptimal aeration and drainage, increases soil strength and decreases root growth; whereas, in coarse-textured soil a reduction of macropore space following compaction increases plant available water, decreases drought stress, and thereby prolongs the growing season. However, coarse-textured soil is more susceptible to forest productivity declines following nutrient removals because of shallow forest floor layers and low soil mineralization rates [7]. Given this current consensus of harvesting effects on soil physical and chemical characteristics, geospatial soil disturbance risk assessments would be advantageous for identifying resilient soils capable of supporting long-term biomass harvesting. Such geospatial risk assessments are now possible over much of the western US as land resource inventory agencies (e.g., Natural Resource Conservation Service, United States Forest Service, United States Geological Service) provide readily available, spatially explicit, digital geology, soil and vegetation resource inventories [29].

Thus, based on the agreement of forest research findings presented above, here we will illustrate an applied methodology for the purpose of geospatially defining areas of soil sensitivity and providing a geospatial mapping tool that can be developed for planning future forest harvest activities. Forest soil productivity risk assessments will be proposed within a geographic information system (GIS) based on soil and geologic parent material properties and thresholds or limits that have been observed to positively or negatively affect forest growth. The objectives are to: (1) present a risk assessment process that is widely applicable across the western US and beyond; (2) provide a unit-level management tool useful to managers, planners or policy makers for both public and private forest lands; and (3) describe best management practices (BMPs) for the differing risks assessed within a selected area of interest.

\section{Materials and Methods}

\subsection{Timberlands of Western US Ecoregions}

Western US forests are found across 16 Level III ecoregions [30] (Figure 1). Each of these forested ecoregions are comprised of forestland and timberland, with timberlands being capable of producing 
$>0.57 \mathrm{~m}^{3} /$ commercial wood volume/yr. The focus of this paper will be upon timberlands of the western US, which are the most likely to have the potential to provide biomass for bioenergy production. These western US timberlands total $\sim 52$ million ha. Of this land base, private timberland accounts for $\sim 18$ million ha and public $\sim 34$ million ha [31].

Figure 1. Forested ecoregions across the western US and the proportion of timberlands held by private and public forest landholders (pie charts). Text reflect the hectares of timberland in each state. The Natural Resource Conservation Service (NRCS) soil survey area-ID612 - denotes the area of interest for this paper.

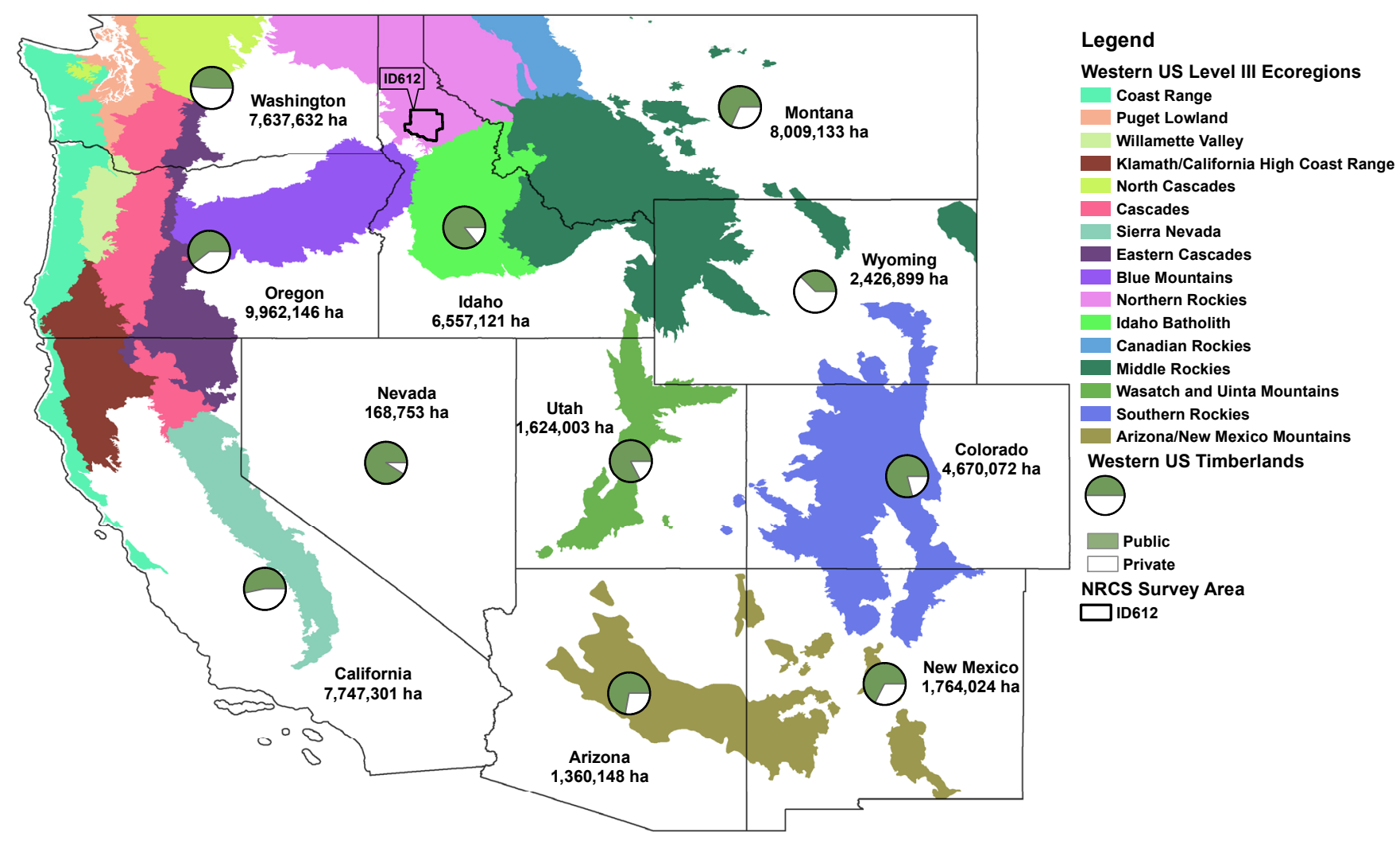

We selected the ID612 soil survey area [32], as an example of an explicitly defined timber producing region within the Northern Rockies ecoregion to demonstrate our proposed forest soil productivity risk rating process (Figure 1). This soil survey area has available updated digital soil and geology surveys that can be used to demonstrate the process of developing spatially explicit risk assessments for soil sensitivity to biomass removal impacts. Our risk assessment approach is applicable across timbered ecoregions of the western US where digital soil and geology surveys are available.

\subsection{Survey Area Physiography}

The ID612 survey is located within the northern Idaho Clearwater Mountains, a sub-range of the Rocky Mountains. This survey area encompasses $\sim 336,000$ ha of diverse physiographic features. Landform is characterized by mountainous landscapes to the north and east, while plateaus and benchlands incised with deep canyons are found in the south and west (Figure 2a). Annual 
precipitation averages $<635 \mathrm{~mm}$ in the southwest and $>1500 \mathrm{~mm}$ in the northeast [33]. Geology is represented by varying lithologies of igneous, metamorphic and sedimentary parent materials (Figure 2b). Common throughout the area are eolian deposits of Columbia Basin loess and Mt. Mazama volcanic ash, often found as intermixed mantles overlying geologic parent material. Volcanic ash mantles $>50 \mathrm{~cm}$ are commonly found in the mountainous regions of the study area. Soil taxonomic classifications across the south are generally Ultic Argixerolls or Vitrandic Fragixeralfs; whereas in the north, Andic Fragiudalfs or Alfic Udivitrands would be typical [32]. Mixed species timberlands dominate this region with ponderosa pine (Pinus ponderosa Dougl.), Douglas-fir [Pseudotsuga menziesii (Mirb.) Franco var. glauca], western redcedar (Thuja plicata Donn) and grand fir [Abies grandis (Douglas ex D. Don) Lindl.] as the primary commercial timber species.

Figure 2. (a) Elevation gradients across the northern Idaho ID612 survey area within the Northern Rockies ecoregion, USA [34]. The blue water body represents the outline of Dworshack Reservoir on the North Fork of the Clearwater River. (b) Geologic parent material across the ID612 survey area representing extrusive and intrusive igneous rocks, metasedimentary and metamorphic rocks, with minor components of unconsolidated deposits [34].

a)

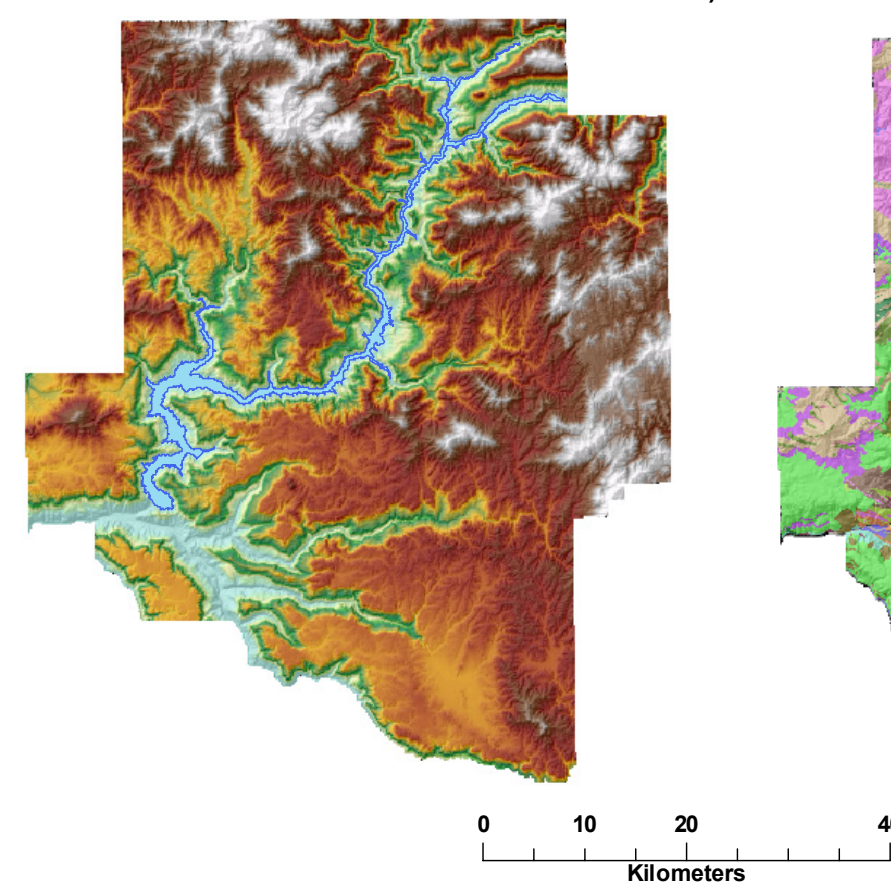

b)
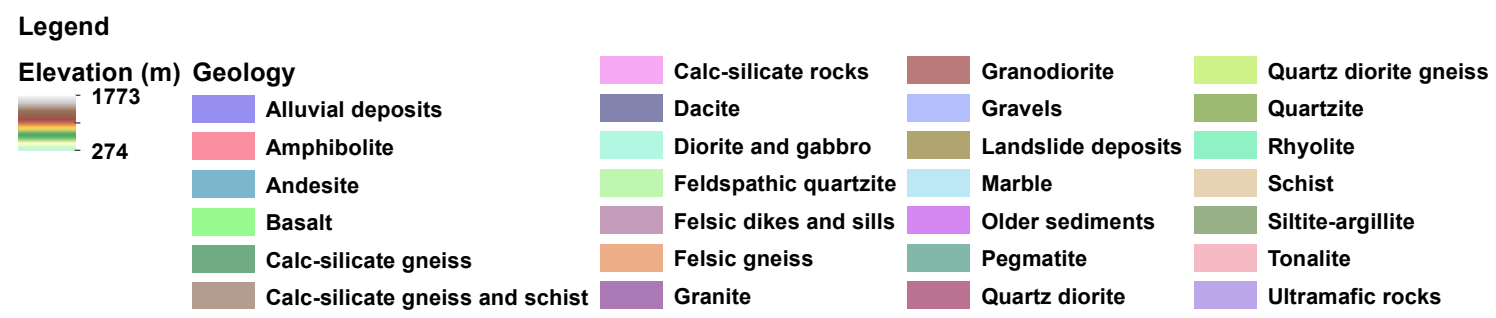


\subsection{Soil Risk Assessments}

The development of soil nutrient and disturbance risk assessments relied on the assembly of a suite of geospatially explicit databases as obtained through the Idaho Geological Survey (IGS), Natural Resource Conservation Service (NRCS), and the Intermountain Forest Tree Nutrition Cooperative (IFTNC). All layers were clipped to represent only landforms with slopes $<45$ percent (i.e., upper limit of ground-based harvest activities) [35]. A 45 percent slope cutoff was deliberately selected over the traditional 35 percent cutoff as ground-based harvesting equipment in the western US is often used on slopes $>35$ percent. Thus, the maximum effect of ground-based operations on steeper slopes would be captured. In addition, landforms with slopes $<45$ percent were deliberately selected for the following analyses as they present the greatest possibility for physical site disturbance from ground based harvesting relative to skyline or helicopter harvesting on steeper slopes [26]. Ground-based harvesting on lower slopes also provide higher financial return for biomass removal compared with higher costs associated with other harvesting approaches.

From these digital sources, preliminary layers illustrating rock nutrient status and surface soil organic matter content were created to develop a chemical soil property-based nutrient status assessment. Similarly, preliminary layers of soil rutting hazard (compaction and displacement) and soil erosion hazard were created to develop a physical soil property-based disturbance susceptibility assessment. The following sections provide more details on the construction of the soil nutrient status and soil disturbance susceptibility risk assessments.

\subsection{Soil Nutrient Status}

Soil nutrient status was derived as a combination of (1) rock nutrient status (Figure 3a) and (2) surface soil organic matter content (Figure $3 \mathrm{~b}$ ). To obtain rock nutrient status, a regional, digital geology map (1:100,000 scale) was used to define the major rock lithologies found within the ID612 survey area [32,34]. These rock lithologies were then classified into one of four rock nutrient classes based on a modified Reiche's weathering potential equation [36] and forest growth and fertilization research by regional forest scientists and geologists (Table 1) [37-39]. Rock nutrient status was categorized and scored as good (score 1), moderate (score 2), poor (score 3) or very poor (score 4). For example, a lithology with high weathering potential (i.e., low Si content) and high cation content ( $\mathrm{K}, \mathrm{Ca}, \mathrm{Mg}, \mathrm{Na}$ ) would be ranked as good. A very poor rock nutrient status would be derived from rocks with low weathering potential (i.e., high Si content) and low cation content. For foresters to derive similar rankings in their regions, they must consult with regional forest and geology research scientists as rock nutrient status is not an inherent output feature of digital geology maps.

Surface soil organic matter content to a depth of $30 \mathrm{~cm}$ was obtained from the ID612 1:24,000 digital soil survey map using the NRCS Soil Data Viewer $5.2^{\circledR}$ extension within ArcGIS 9.3 ${ }^{\circledR}$ (Figure 3b) [32,40]. A soil condition weighted average of percent organic matter content in the surface soil was used to obtain a single value within a soil mapping unit. This was necessary as there are often more than one soil component with varying physical and chemical features within a single mapping unit. A spatial delimiter was used to exclude minor soil components from unduly influencing a mapping unit average. Components were excluded if they occupied 25 percent or less of the land area 
in a mapping unit. A 25 percent threshold was used due to the complex topography associated with this study area. In regions with less topography, a smaller threshold (e.g., 5-15 percent) would be more appropriate. The weighted map unit average of percent soil organic matter content was then manually classed and scored into four levels: very high ( $>12 \%$ organic matter content, score 1$)$, high (8-12\% organic matter content, score 2$)$, medium (4-8\% organic matter content, score 3$)$ and low $(<4 \%$ organic matter content, score 4). These classes, although arbitrary, reflect the relative levels of surface soil organic matter content in this region. These classifications are not necessarily reflective of the range of values found in other regions across the western US and each region of interest should be approached individually to define a regionally pertinent nutrient and organic matter status.

Figure 3. (a) Relative geologic soil parent material nutrition across the ID612 survey area of the Northern Rockies ecoregion, USA [36-39]; (b) Surface soil organic matter classes to a depth of $30 \mathrm{~cm}$ across the ID612 survey area [32,40,41]. Gray scale areas represent excluded landforms with $>45$ percent slope [35].

a)

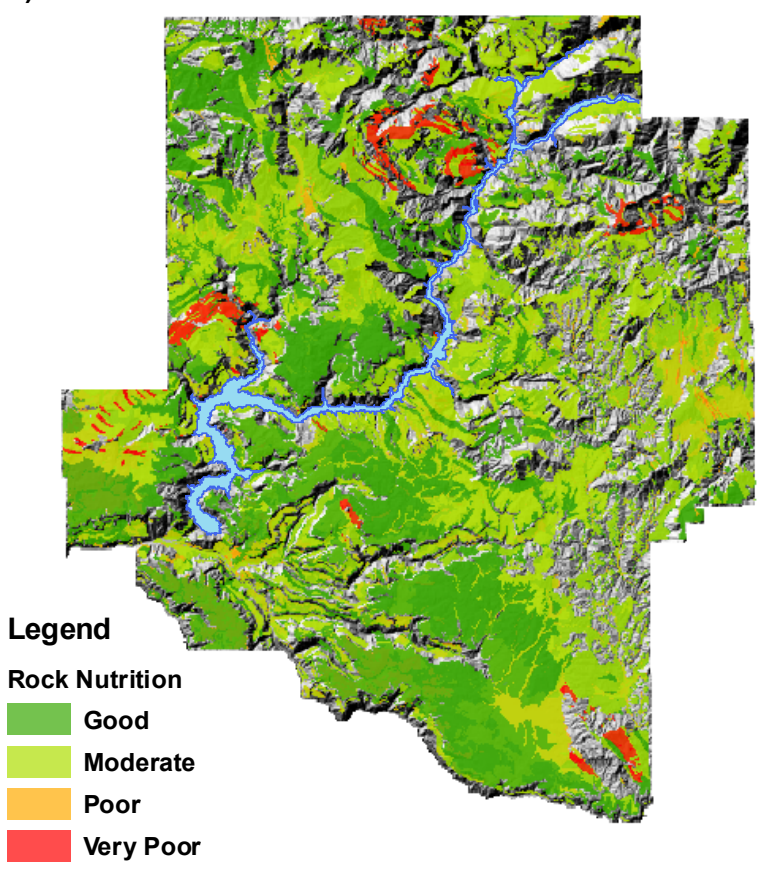

b)

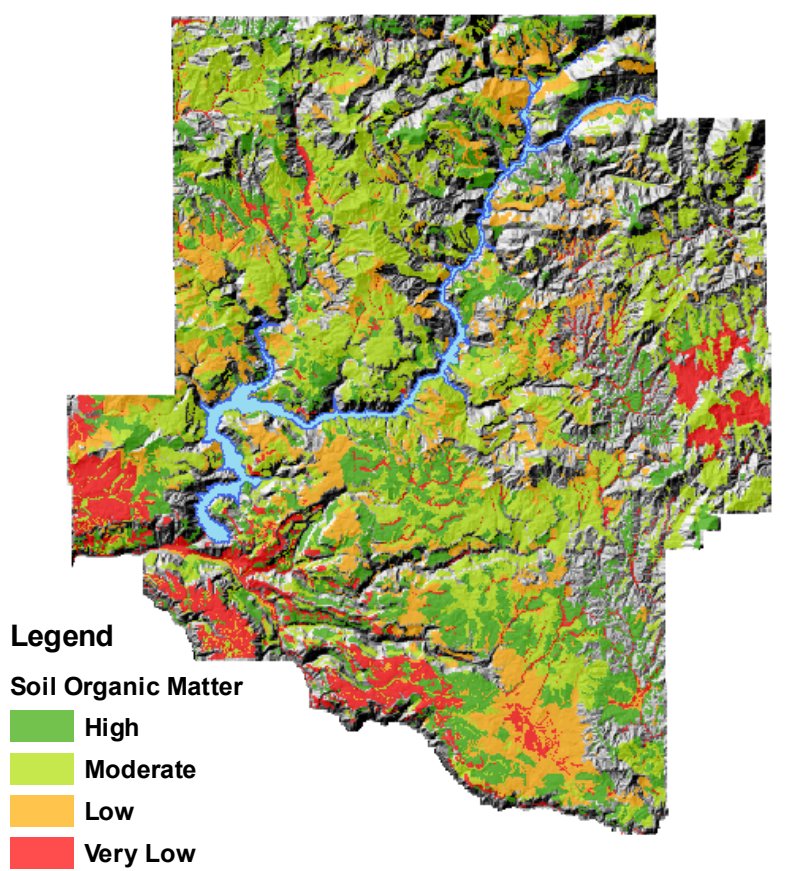

Table 1. Rock nutrient status as a function of weathering potential and forest soil nutrition research across the ID612 survey area of the Northern Rockies ecoregion, USA [34,36-39].

\begin{tabular}{llll}
\hline \multicolumn{3}{c}{ Rock Nutrient Status } & \\
\hline Good (1) & Moderate (2) & Poor (3) & Very Poor (4) \\
\hline Basalt, & Alluvium, & Amphibolite, Andesite, Dacite, & Quartzite \\
Calc-silicate rocks & Felsic gneiss, Granite, & Diorite/Gabbro, & \\
& Granodiorite, & Feldspathic Quartzite, & \\
& Quartz Diorite, Schist, & Felsic Dikes/Sills, Gravels, Marble, & \\
& Siltite/Argillite, Tonalite & Pegmatite, & \\
& & Quartz Diorite Gneiss, Rhyolite, & \\
& & Ultramafics \\
\hline
\end{tabular}




\subsection{Soil Disturbance Susceptibility}

Soil disturbance susceptibility was built on (1) soil rutting hazard (i.e., compaction and displacement) (Figure 4a) and (2) soil erosion hazard (Figure 4b). These assessments were obtained from the ID612 1:24,000 digital soil survey map using the NRCS Soil Data Viewer 5.2 ${ }^{\circledR}$ extension within ArcGIS 9.3 ${ }^{\circledR}[32,40]$. Similar to soil organic matter content, a soil condition weighted average was used with a 25 percent component delimiter to obtain a single classification rating for each mapping unit within the survey area.

Figure 4. (a) Soil compaction hazard across the ID612 survey area of the Northern Rockies ecoregion, USA [32,40,41]; (b) Sheet and rill erosion hazard across the ID612 survey area $[32,40,41]$. Gray scale areas represent excluded landforms with $>45$ percent slope [35].

a)

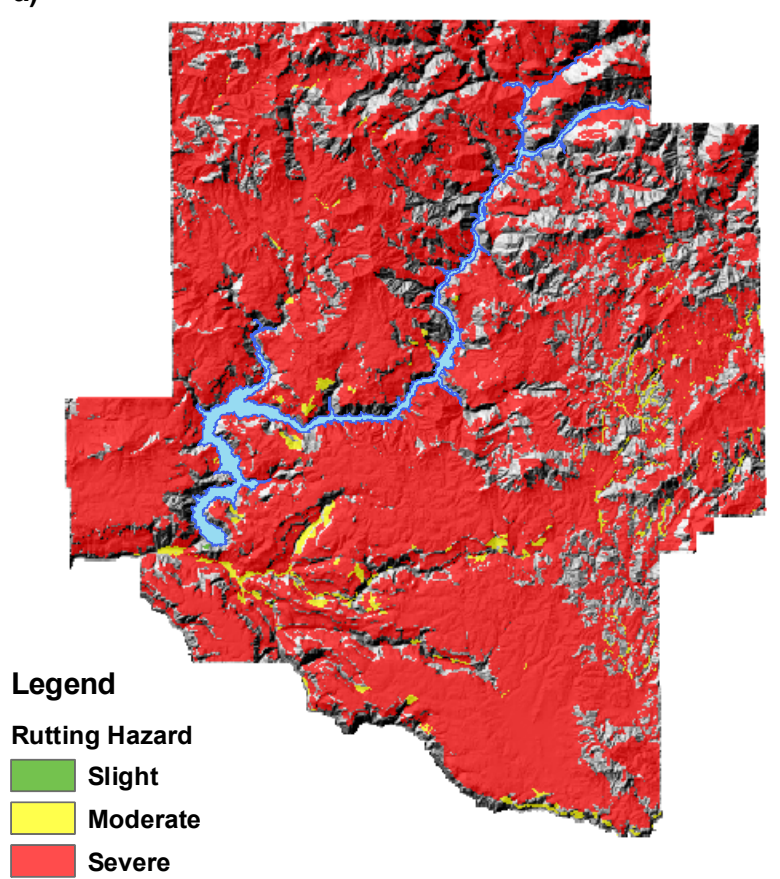

b)

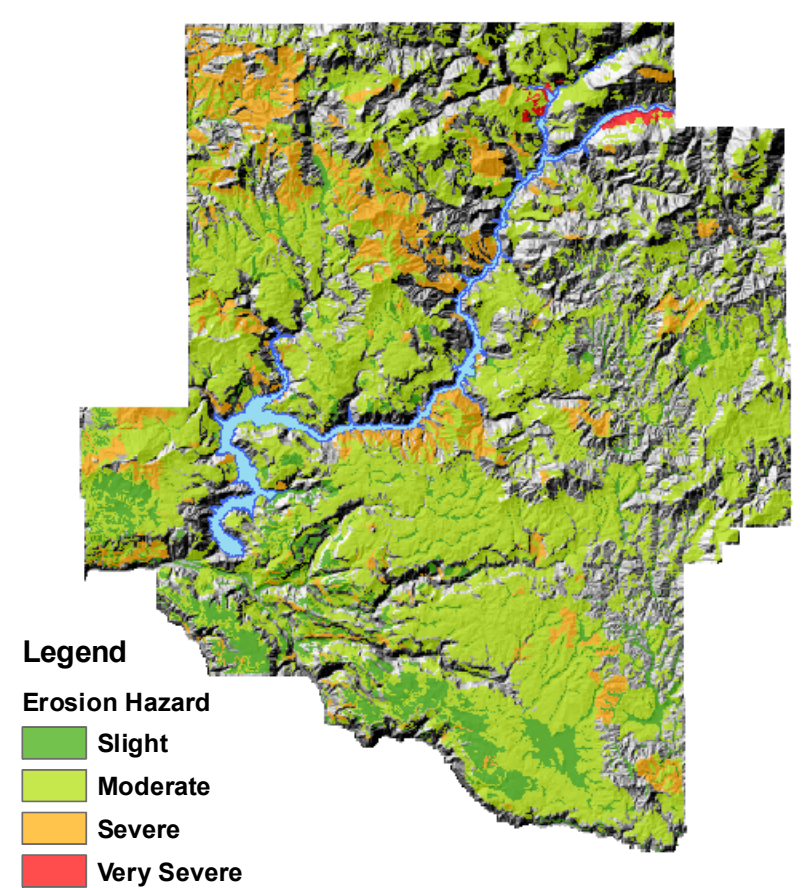

Soil rutting hazards were developed by the NRCS based on the following considerations: (1) 3-10 passes of equipment on soils near field capacity, (2) operation of standard, non-flotation rubber tired equipment, (3) year-long water tables $<30 \mathrm{~cm}$ from the soil surface, and (4) soil displacement and puddling that may affect groundwater hydrology and productivity of the site. Rankings were defined as an interaction between depth to water table, rock fragments on or below the soil surface, the Unified Classification Group (textural classes) and slope (Table 2) [41]. For example, shallow soils with high coarse fragments and/or coarse texture on flat terrain would not be expected to rut easily, and would thus be ranked as a slight rutting hazard. Conversely, deep, fine-textured soils, with little coarse fragments on steeper slopes would rut and compact readily, and would thus be ranked as a severe rutting hazard. Rutting hazards were classed and scored as slight (score 1), moderate (score 2) and severe (score 3) (Table 2). 
Table 2. NRCS soil rutting hazard as a function of soil texture, depth to water table and soil rock fragment content for the ID612 survey area of the Northern Rockies ecoregion, USA. Steeper slope classes (e.g., $>20 \%$ ) may shift ratings to one class more limiting [41].

\begin{tabular}{|c|c|c|c|}
\hline & \multicolumn{3}{|c|}{ Soil Rutting Hazard } \\
\hline & \multicolumn{3}{|c|}{$\begin{array}{c}\text { Unified Soil Texture Classification }{ }^{\dagger} \\
\text { (thickest layer with upper boundary } \leq 10 \mathrm{~cm} \text { of the surface) }\end{array}$} \\
\hline & Slight (1) & Moderate (2) & Severe (3) \\
\hline \multicolumn{4}{|l|}{ Water Table } \\
\hline $\begin{array}{l}\text { Maximum depth to wet layer }<30 \mathrm{~cm} \\
\text { for } 12 \text { months of the year }\end{array}$ & -- & -- & All Groups \\
\hline \multicolumn{4}{|l|}{ Rock Fragments } \\
\hline$>75 \mathrm{~mm}$ in size, $<20 \%$ by volume & $\begin{array}{l}\text { GW, GP, GM, GW- } \\
\text { GM, GCGM,GW- } \\
\text { GC,GP-GM, GP-GC }\end{array}$ & $\begin{array}{l}\text { GC, SW, SP,SM, SC, } \\
\text { SWSM, SW-SC, SP- } \\
\text { SM, SP-SC, SC-SM }\end{array}$ & $\begin{array}{l}\mathrm{CL}, \mathrm{CH}, \mathrm{CLML}, \mathrm{ML} \text {, } \\
\mathrm{MH}, \mathrm{OL}, \mathrm{OH}, \mathrm{PT}\end{array}$ \\
\hline $\begin{array}{l}>75 \mathrm{~mm} \text { in size, }>20 \% \text { by volume; OR } \\
>3 \% \text { to }<10 \% \text { surface cover, }>75 \mathrm{~mm} \\
\text { in size; OR } \\
\text { depth to top of bedrock paralithic, } \\
\text { bedrock lithic; OR } \\
\text { duripan restrictive layer }<15 \mathrm{~cm} \\
\end{array}$ & $\begin{array}{l}\text { GW, GP, GM, GW- } \\
\text { GM, GCGM, GW-GC, } \\
\text { GP-GM, GP-GC, GC, } \\
\text { SW, SP, SM, SC, } \\
\text { SWSM, SW-SC, } \\
\text { SPSM, SP-SC, SCSM }\end{array}$ & $\begin{array}{l}\mathrm{CL}, \mathrm{CH}, \mathrm{CLML}, \mathrm{ML} \text {, } \\
\mathrm{MH}, \mathrm{OL}, \mathrm{OH}, \mathrm{PT}\end{array}$ & -- \\
\hline$>10 \%$ surface cover & All Groups & -- & -- \\
\hline
\end{tabular}

Soil erosion hazards were developed by the NRCS based on the following considerations: (1) soil susceptibility to sheet and rill erosion from exposed mineral soil surfaces caused by various harvest practices; (2) operational activities that disturb organic surface material resulting in 50 to 75 percent bare ground in the affected area; and (3) the use of any equipment type or size. Rankings were defined as an interaction between slope and the soil erosion factor $K_{w}$ (Table 3) [41]. $K_{w}$, which is used within the Revised Universal Soil Loss Equation (RUSLE), is a function of percent silt, sand and organic matter, soil structure and saturated hydraulic conductivity [42]. Slight soil erosion would be expected to occur on flatter terrain, or on soils with high mineral soil organic matter content and saturated hydraulic conductivity, as well as abundant soil cover (surface organic matter, moss, understory vegetation, etc.); whereas, severe soil erosion would occur on those soils with low saturated hydraulic conductivity, steeper slopes, and little protective soil cover. Based on these criteria, soil erosion susceptibility rankings following harvest activities were classified and scored as slight (score 1), moderate (score 2), severe (score 3) and very severe (score 4) (Table 3). 
Table 3. NRCS soil erosion hazard as a function of slope and the soil erosion factor $K_{\mathrm{w}}$ for the ID612 survey area of the Northern Rockies ecoregion, USA [41].

\begin{tabular}{lcccc}
\hline \multicolumn{5}{c}{ Soil Erosion Hazard } \\
\cline { 2 - 5 } & Slight (1) & \multicolumn{4}{c}{ Moderate (2) } & Severe (3) & Very Severe (4) \\
\hline $\mathbf{K}_{\mathbf{w}}^{\dagger}$ & \multicolumn{5}{c}{ Slope (\%) } \\
\hline $\mathrm{K}_{\mathrm{w}}<0.35$ & $0-14$ & $15-35$ & $36-50$ & $>50$ \\
$\mathrm{~K}_{\mathrm{w}} \geq 0.35$ & $0-9$ & $10-25$ & $26-40$ & $>40$ \\
\hline
\end{tabular}

$\uparrow$ Soil erosion factor within the thickest mineral horizon $0-15 \mathrm{~cm}$.

\subsection{Soil Nutrient and Disturbance Risk Assessments}

Final risk assessment maps for both soil nutrition and disturbance susceptibility following ground-based harvest treatments were derived by: (1) assigning equal weights to each layer's classification score on a 30 m pixel basis; (2) summing the class scores at each pixel; and (3) obtaining the average pixel score. The average scores across the pixels were then classed into four risk rating categories: low (score 1-1.5), moderate (score 2-2.5), high (score 3-3.5) and severe (score 4) (Figure 5a,b).

Figure 5. (a) Nutrient risk assessment to long-term soil productivity following ground-based harvest activities in the ID612 survey area of the Northern Rockies ecoregion, USA; (b) Soil disturbance risk assessment to long-term soil productivity following ground-based harvest activities in the ID612 survey area. Gray scale areas represent excluded landforms with $>45$ percent slope [35].

a)

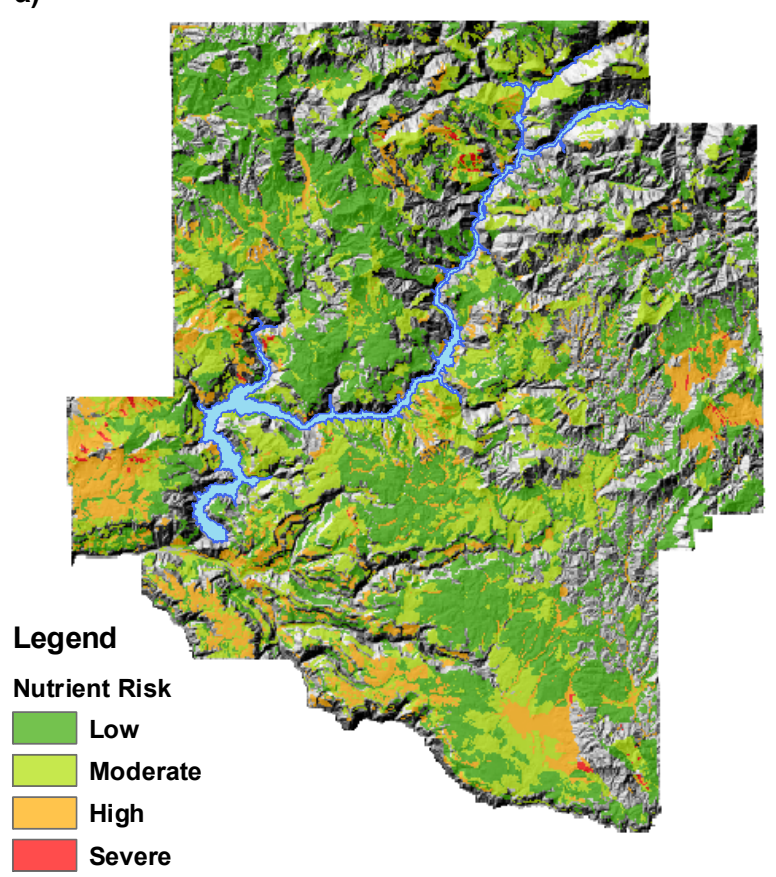

b)

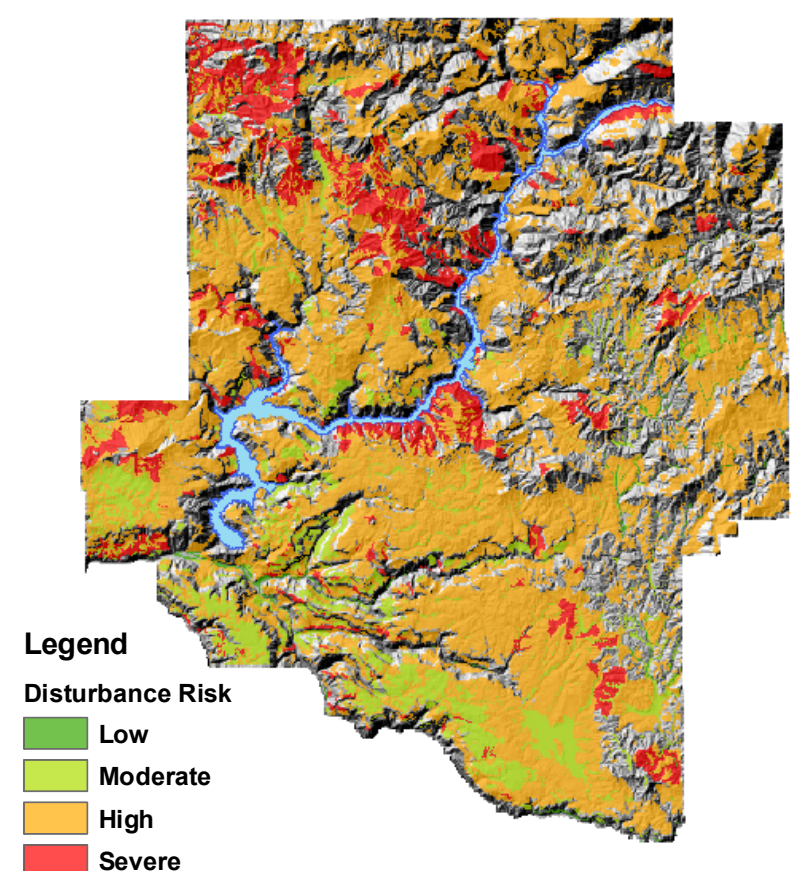




\section{Results and Discussion}

\subsection{Soil Nutrient Status}

Rock nutrition across the ID612 survey area was shown to have moderate to good status (Figure 3a) [37]. The primary rock types associated with these classifications were igneous basalt and granite, schist, and carbonate/calcium-rich metasediments. Nutrient poor and very poor parent materials were primarily associated with metasedimentary quartzite and some formations of siltite/argillite, which composed a relatively small proportion of the timberland base [37].

Surface soil organic matter content was loosely correlated with climatic zones found in the region (data not shown). Warmer temperatures and lower precipitation in the south and west of the survey area produce sparse forested communities, thus less organic matter returned annually to the soil, and higher decomposition rates (Figure 3b). However, as precipitation increases to the north, forest biomass increases, returning greater amounts of organic matter annually to the soil. Despite higher organic matter inputs in the north, colder air and soil temperatures usually results in lower decomposition rates (Figure 3b).

These results suggest that across the majority of the soils in ID612 there is minimal risk of long-term soil productivity loss due to nutrient removals following biomass harvesting (Figure 5a). However, in the drier ecotypes where biomass production is low and nutrient cycling more rapid, there is a significantly greater risk of nutrient loss, and thus long-term soil productivity loss, if both forest biomass and soil organic matter are removed or displaced.

\subsection{Soil Disturbance Susceptibility}

With very little exception, the majority of ID612 soils are susceptible to severe rutting (i.e., compaction and displacement) following ground-based harvest activities (Figure 4a). Surface soil parent material, slope and their interaction are the primary factors responsible for this rating. Many of the soil mapping units in this survey area are covered by a variably thick surface mantle of loamy-mixed volcanic ash [32]. These ash-influenced soils are fine-textured, have a friable to weak subangular blocky soil structure and are relatively free of coarse fragments, rendering them highly susceptible to rutting. Further, as landform slope increases, equipment operation exacerbates soil compaction and displacement due to unbalanced axle weight allocation as machinery traverses up, down or across slope. Soil rutting is also increased as equipment operation continues when the soils are near field water capacity.

Unlike soil rutting, soil erosion susceptibility for ID612 falls predominately into a slight or moderate hazard rating (Figure $4 \mathrm{~b}$ ). The areas that show severe to very severe soil erosion hazards are primarily an integrative function of high silt content and increasing slope (data not shown). Soils high in silt content are more susceptible to erosion following loss of organic matter cover as they are easily detached; tend to crust and generate high rates of runoff [43]. The majority of the soils throughout this region however, are capable of absorbing water inputs due to moderate/high soil organic matter content and/or a balanced texture of sand, silt and clay. 


\subsection{Best Management Practices}

A comparison of the integrated nutrient and disturbance risk assessments suggest that loss of nutrients following harvest treatments in ID612 is less of a concern to future soil productivity than is displacement and compaction of the organic rich surface soil (Figure 5a,b). While nutrient loss may be a concern in some areas within the ID612 region, the loss of soil water holding capacity and increased soil strength following compaction of fine-textured soils are of particular concern. Vulnerable soils are capable of losing significant ecosystem function through compaction and displacement, which in turn affects long-term soil-site productivity [7]. Consequently, it is appropriate that best management practices are developed to guide silvicultural prescriptions in order to maintain soil function in this region.

The development of the soil chemical and physical property risk assessment maps allows us to now spatially define specific best management practices for ground-based harvest treatments across the ID612 survey area. Based on the most current literature reviews [7,43] of harvest effects on soil-site productivity in this region, we developed guidelines for biomass removal, appropriate harvest season and machine traffic limitations (Table 4). Land resource managers can then link these geospatial recommendations within their management information systems to provide long-term silvicultural guidance.

We recognize that these BMPs are only the first step towards developing a risk assessment system. Long-term forest soil sustainability is often more influenced by ephemeral conditions such as snow pack, soil moisture, surface organic horizons, and operator skill than by chemical or physical limitations within the soil [26]. However, this tool allows land managers to make informed decisions about harvest systems based on site limitations, improve site selection criteria and provide an understanding of the possible soil impacts during harvest operations.

In addition, we recognize that this model does not account for alterations in soil biological properties. Usually nitrogen $(\mathrm{N})$ is the key nutrient limiting growth in western US forests, and its availability is dependent on soil microbial activity [7]. Often $\mathrm{N}$ changes can be linked to changes in soil temperature (removal of the canopy or logging slash). As temperature increases, organic matter on the soil surface and within the mineral soil decomposes rapidly, increasing mineralizable $\mathrm{N}$ rates [44]; albeit, large amounts of logging slash on the soil surface may increase immobilization of nutrients until the residues are decayed [45]. However, it is crucial to remember that many belowground processes are linked to the retention of coarse woody debris. Thus, any biomass removal operation on public (or private) forest timberland should avoid large losses of coarse woody material in order to maintain ecological function [7].

As with other forest management practices, biomass removal for energy production or forest health requires attention to individual site characteristics and consideration of management objectives as well as long-term sustainability [22]. The risk assessments and best management practices proposed here highlight the relative ease with which soil chemical and physical properties can be assessed and linked together to help guide land management decisions. 
Table 4. Best management practices for maintaining soil productivity during ground-based biomass harvest activities by risk assessment class in the ID612 survey area of the Northern Rockies ecoregion, USA. Table colors intended to reflect risk rating color scheme in Figure 5.

\begin{tabular}{|c|c|c|}
\hline $\begin{array}{l}\text { Risk } \\
\text { Assessment }\end{array}$ & Soil Chemical BMPs & Soil Physical BMPs \\
\hline Low & $\begin{array}{l}\text { - Any ground-based harvest method } \\
\text { acceptable } \\
\text { - Fertilization not necessary to } \\
\text { maintain soil nutrient status } \\
\text { - Minimize forest floor disturbance }\end{array}$ & $\begin{array}{l}\text { - Feller buncher }{ }^{1} \text { or cut-to-length }{ }^{2} \text { harvesters } \\
\text { acceptable on shallow slopes } \\
\text { - Cut-to-length harvesters and forwarders (with } \\
\text { travel corridors and biomass mats) preferred on } \\
\text { steeper slopes } \\
\text { - Ensure soils are not at high water capacity before } \\
\text { harvest activities } \\
\text { Minimize forest floor disturbance to reduce soil } \\
\text { erosion, compaction and other soil disturbance }\end{array}$ \\
\hline Moderate & $\begin{array}{l}\text { Bole only harvesting recommended } \\
\text { - Whole tree harvesting acceptable } \\
\text { with post-harvest fertilization } \\
\text { recommended on nutrient poor soils } \\
\text { - Minimize forest floor disturbance }\end{array}$ & $\begin{array}{l}\text { - Manual felling or cut-to-length harvesting (with } \\
\text { travel corridors and biomass mats) preferred on all } \\
\text { slope conditions } \\
\text { - Late summer to early fall harvesting only } \\
\text { - Minimize forest floor disturbance to reduce soil } \\
\text { erosion, compaction and other soil disturbance }\end{array}$ \\
\hline High & $\begin{array}{l}\text { - Bole only harvesting recommended } \\
\text { Post-harvest fertilization } \\
\text { recommended } \\
\text { Maintain the forest floor, minimize } \\
\text { removal of branches, twigs and dead } \\
\text { wood. }\end{array}$ & $\begin{array}{l}\text { - Feller buncher harvesting not recommended } \\
\text { - } \text { Manual felling preferred } \\
\text { shovel/tractor yarding acceptable when limited to } \\
\text { designated skid trails with biomass mats no less } \\
\text { than } 12 \text { inches thick } \\
\text { - Late summer to early fall harvesting only } \\
\text { - Consider winter logging to reduce compaction, } \\
\text { rutting and erosion }\end{array}$ \\
\hline Severe & $\begin{array}{l}\text { Intensive biomass harvesting not } \\
\text { recommended } \\
\text { - Forest health maintenance } \\
\text { harvesting only } \\
\text { - Leave all branches, twigs and } \\
\text { maintain the forest floor } \\
\text { - Consider fertilization }\end{array}$ & $\begin{array}{l}\text { - } \text { Manual felling only } \\
\text { - Shovel/Tractor yarding limited to winter only } \\
\text { - } \quad \text { Ensure equipment is matched to site } \\
\text { - Monitor soil moisture } \\
\text { - } \quad \text { Maintain forest floor } \\
\text { - Use slash mats and/or balloon tires on wet soil }\end{array}$ \\
\hline
\end{tabular}

\footnotetext{
${ }^{1}$ Feller buncher-A motorized vehicle with a grip and cutting attachment that can rapidly cut and gather several trees before felling and bunching them for subsequent forwarding to a landing for delimbing and bucking. ${ }^{2}$ Cut-to-length-A motorized vehicle capable of gripping, felling, delimbing and bucking a tree at the stump.
} 


\section{Conclusions}

Forest management practices for energy production should ensure maintenance of long-term soil productivity. To accomplish this, site specific considerations of management objectives can be linked geospatially by using available nutrient data, soil survey data and geology layers, as demonstrated through the development of the proposed risk assessments. The key soil properties that affect soil disturbance, compaction, erosion or nutrient depletion (e.g., soil texture, slope, surface cover and geology) are relatively easy to access from land resource mapping agencies. However, understanding how these changes alter tree nutrition or growth comes from having long-term data on various forest trees species across a variety of stand types and site conditions. In areas where this data is not available, existing literature may provide guidance.

Based on our proposed risk rating system and review of the available literature, we developed biomass harvest best management practices that adapt management to the varying chemical and physical soil conditions inherent to western US forests. The proposed soil chemical and physical property risk assessment process can be expanded to other regions across the western US where digital soil and geologic information is available. Such an approach would aid in identifying resilient soils for forest land managers considering biomass operations, policy makers contemplating expansion of biomass harvesting and investors deliberating where to locate bioenergy conversion facilities.

\section{Acknowledgments}

The authors wish to thank Steve Campbell (NRCS-Portland, OR, USA), Steve Peaslee (NRCS-Lincoln, NE), Brad Duncan (NRCS-Spokane, WA, USA), Hal Lindsay (NRCS-Boise, ID, USA), Reed Lewis (IGS-Moscow, ID, USA) and Mariann Garrison-Johnston (SUNY-ESF, Wanakena, NY, USA) for providing guidance in the development of the soil property risk ratings.

\section{References and Notes}

1. Fox, T.R. Sustained productivity in intensively managed forest plantations. For. Ecol. Manag. 2000, 138, 187-202.

2. Neilson, D.; Manners, G. The Global Tree Farm and Managed Forest Industry; Dana Publishing: Rotura, New Zealand, 2003.

3. Neilson, D.; Flynn, B.; Belton, M. The Global Douglas-Fir Industry-Outlook on Changing Resources and Markets; Dana Publishing: Rotura, New Zealand, 2001.

4. Talbert, C.; Marshall, D. Plantation productivity in the Douglas-fir region under intensive silvicultural practices: Results from research and operations. J. For. 2005, 103, 65-70.

5. Grigal, D.F. Effects of extensive forest management on soil productivity. For. Ecol. Manag. 2000, $138,167-185$.

6. White, E.M. Woody biomass for bioenergy and biofuels in the United States-A briefing paper. General Technical Report PNW-GTR-825; U.S. Department of Agriculture, Forest Service, Pacific Northwest Research Station: Portland, OR, USA, 2010. 
7. Page-Dumroese, D.S.; Jurgensen, M.; Terry, T. Maintaining soil productivity during forest or biomass-to-energy thinning harvests in the western United States. West J. Appl. For. 2010, 25, 5-11.

8. Westerling, A.L.; Hidalgo, H.G.; Cayan, D.R.; Swetnam, T.W. Warming and earlier spring increase western U.S. forest wildfire activity. Science 2006, 313, 940-943.

9. Man, G. Major forest insect and disease conditions in the United States: 2009 update. FS-952; U.S. Department of Agriculture, Forest Service, Washington Office: Washington, DC, USA, 2009.

10. Mann, L. Effects of whole-tree and stem-only clearcutting on postharvest hydrologic losses, nutrient capital, and regrowth. For. Sci. 1988, 34, 412-428.

11. Miller, R.E.; Scott, W.; Hazard, J.W. Soil compaction and conifer growth after tractor yarding at three coastal Washington locations. Can. J. For. Res. 1996, 26, 225-236.

12. Zabowski, D.; Java, B.; Scherer, G.; Everett, R.L.; Ottmar, R. Timber harvesting residue treatment: Part 1. Responses of conifer seedlings, soils and microclimate. For. Ecol. Manag. 2000, 126, 25-34.

13. Gomez, A.; Powers, R.F.; Singer, M.J.; Horwath, W.R. N uptake and $\mathrm{n}$ status in ponderosa pine as affected by soil compaction and forest floor removal. Plant Soil 2002, 242, 263-275.

14. Piatek, K.B.; Harrington, C.A.; DeBell, D.S. Site preparation effects on 20 year survival and growth of Douglas-fir (Pseudotsuga menziesii) and on selected soil properties. West J. Appl. For. 2003, 18, 44-51.

15. Ares, A.; Terry, T.A.; Miller, R.E.; Anderson, H.W.; Flaming, B.L. Ground-based forest harvesting effects on soil physical properties and Douglas-fir growth. Soil Sci.e Soc. Am. J. 2005, 69, 1822-1832.

16. Powers, R.F.; Scott, D.A.; Sanchez, F.G.; Voldseth, R.A.; Page-Dumroese, D.; Elioff, J.D.; Stone, D.M. The North American long-term soil productivity experiment: Findings from the first decade of research. For. Ecol. Manag. 2005, 220, 31-50.

17. Jurgensen, M.F.; Harvey, A.E.; Graham, R.T.; PageDumroese, D.S.; Tonn, J.R.; Larsen, M.J.; Jain, T.B. Impacts of timber harvesting on soil organic matter, nitrogen, productivity, and health of Inland Northwest forests. For. Sci. 1997, 43, 234-251.

18. Johnson, D.W.; Curtis, P.S. Effects of forest management on soil C and N storage: Meta analysis. For. Ecol. Manag. 2001, 140, 227-238.

19. Bennett, L.T.; Adams, M.A. Assessment of ecological effects due to forest harvesting: Approaches and statistical issues. J. Appl. Ecol. 2004, 41, 585-598.

20. Burger, J.A. Management effects on growth, production and sustainability of managed forest ecosystems: Past trends and future directions. For. Ecol. Manag. 2009, 258, 2335-2346.

21. Lattimore, B.; Smith, C.T.; Titus, B.D.; Stupak, I.; Egnell, G. Environmental factors in woodfuel production: Opportunities, risks, and criteria and indicators for sustainable practices. Biomass Bioenerg. 2009, 33, 1321-1342.

22. Janowiak, M.K.; Webster, C.R. Promoting ecological sustainability in woody biomass harvesting. J. For. 2010, 108, 16-23.

23. Nave, L.E.; Vance, E.D.; Swanston, C.W.; Curtis, P.S. Harvest impacts on soil carbon storage in temperate forests. For. Ecol. Manag. 2010, 259, 857-866. 
24. Han, S.K.; Han, H.S.; Page-Dumroese, D.S.; Johnson, L.R. Soil compaction associated with cut-to-length and whole-tree harvesting of a coniferous forest. Can. J. For. Res. 2009, 39, 976-989.

25. Heninger, R.L.; Terry, T.A.; Dobkowski, A.; Scott, W. Managing for sustainable site productivity: Weyerhaeuser's forestry perspective. Biomass Bioenerg. 1997, 13, 255-267.

26. Reeves, D.; Page-Dumroese, D.; Coleman, M. Detrimental soil disturbance associated with timber harvest systems on National Forests in the Northern Region. Research Paper RMRS-RP-89; U.S. Department of Agriculture, Forest Service, Rocky Mountain Research Station: Fort Collins, CO, USA, 2011.

27. Homann, P.S.; Sollins, P.; Chappell, H.N.; Stangenberger, A.G. Soil organic carbon in a mountainous forested region: Relation to site characteristics. Soil Sci.e Soc. Am. J. 1995, 59, 1468-1475.

28. Hayes, J.P.; Schoenholtz, S.H.; Hartley, M.J.; Murphy, G.; Powers, R.F.; Berg, D.; Radosevich, S.R. Environmental consequences of intensively managed forest plantations in the Pacific Northwest. J. For. 2005, 103, 83-87.

29. Reeves, D. Soil Disturbance Monitoring of Timber Harvest Operations in the USDA Forest Service Northern Region. M.S. Thesis, University of Idaho: Moscow, ID, USA, 2011.

30. United States Environmental Protection Agency, Level III and IV ecoregions of the Continental United States; Western Ecology Division, US EPA: Corvallis, OR, USA, 2011. Available online: http://www.epa.gov/wed/pages/ecoregions/level_iii_iv.htm (accessed on 20 June 2011).

31. Smith, W.B.; Miles, P.D.; Perry, C.H.; Pugh, S.A. Forest resources of the United States. General Technical Report WO-78; U.S. Department of Agriculture, Forest Service, Washington Office: Washington, DC, USA, 2009.

32. Soil Survey Staff. Soil survey geographic (SSURGO) Database for Clearwater, Idaho; Natural Resource Conservation Service, United States Department of Agriculture: Auburn, AL, USA, 2011. Available online: http://soildatamart.nrcs.usda.gov (accessed on 20 June 2011).

33. Digital Precipitation for Idaho: Average, Monthly, and Annual (1961-1990); Idaho State Climate Services: Moscow, ID, USA, 2000.

34. Lewis, R.S.; Burmester, R.F.; McFaddan, M.D.; Kauffman, J.D.; Doughty, P.T.; Oakley, W.L.; Frost, T.P. Geologic map of the Headquarters $30 \times 60$ minute quadrangle, Idaho. Idaho Geological Survey: Moscow, ID, USA, 2007; Idaho Geological Survey Map 92, scale 1:100,000.

35. United States Geological Survey, United States Department of Interior. 1-arc second National Elevation Dataset: NED_31882865; U.S. Geological Survey (USGS): Sioux Falls, SD, USA, 2011. Available online: http://seamless.usgs.gov/ned1.php (accessed on 20 June 2011).

36. Reiche, P. Graphic representation of chemical weathering. J. Sed. Petrol. 1943, 13, 58-68.

37. Garrison-Johnston, M.T.; Lewis, R.; Johnson, L. Northern Idaho and western Montana nutrition guidelines by rock type. IFTNC Report Number 200710. Intermountain Forest Tree Nutrition Cooperative, College of Natural Resources, University of Idaho: Moscow, ID, USA, 2007.

38. Shen, G.H.; Moore, J.A.; Hatch, C.R. The effect of habitat type and rock type on individual tree basal area growth response to nitrogen fertilization. Can. J. For. Res. 2000, 30, 613-623. 
39. Moore, J.A.; Mika, P.G. Influence of soil parent material on the nutrition and health of established conifer stands in the Inland Northwest. In Proceedings of Forest Seedling Nutrition from the Nursery to the Field, Corvallis, OR, USA, 28-29 October 1997; Haase, D.L., Rose, R., Eds.; Nursery Technology Cooperative, Department of Forest Science, Oregon State University: Corvallis, OR, USA, 1997; pp. 112-117.

40. Soil Survey Staff. Soil Data Viewer 5.2 User Guide; Natural Resource Conservation Service, United States Department of Agriculture: Washington, DC, USA, 2008. Available online: $\mathrm{ftp}$ //ftp-fc.sc.egov.usda.gov/NSSC/Soil_Data_Viewer/Soil_Data_Viewer_5_2_User_Guide.pdf (accessed on 20 June 2011).

41. National Forestry Manual. 190-V-NFM; US Department of Agriculture, National Resources Conservation Service (NRCS): Washington, DC, USA, 1998.

42. User's Reference Guide: Revised Universal Soil Loss Equation-Version 2; U.S. Department of Agriculture, Argicultural Research Service: Washington, DC, USA, 2008.

43. Elliot, W.J. Effects of forest biomass use on watershed processes in the western United States. West J. Appl. For. 2010, 25, 12-17.

44. Smethurst, P.J.; Nambiar, E.K.S. Effects of slash and litter management on fluxes of nitrogen and tree growth in a young pinus-radiata plantation. Can. J. For. Res. 1990, 20, 1498-1507.

45. Thibodeau, L.; Raymond, P.; Camire, C.; Munson, A.D. Impact of precommercial thinning in balsam fir stands on soil nitrogen dynamics, microbial biomass, decomposition, and foliar nutrition. Can. J. For. Res. 2000, 30, 229-238.

(C) 2011 by the authors; licensee MDPI, Basel, Switzerland. This article is an open access article distributed under the terms and conditions of the Creative Commons Attribution license (http://creativecommons.org/licenses/by/3.0/). 